This report was prepared as an account of work sponsored by an agency of the United States Government. Neither the United States Government nor any agency thereof, nor any of their employees, makes any warranty, express or implied, or assumes any legal liability or responsibility for the accuracy, completeness, or usefulness of any information, apparatus, product, or process disclosed, or represents that its use would not infringe privately owned rights. Reference herein to any specific commercial product, process, or service by trade name, trademark, manufacturer, or otherwise does not necessarily constitute or imply its endorsement, recommendation, or favoring by the United States Government or any agency thereof. The views and opinions of authors expressed herein do not necessarily state or reflect those of the United States Government or any agency thereof.

\title{
Thermal Modeling of \\ Tanks 241-AW-101 and 241-AN-104 with the TEMPEST Code
}

\author{
Z. I. Antoniak \\ K.P. Recknagle
}

July 1995

Prepared for

the U.S. Department of Energy

under Contract DE-AC06-76RLO 1830

Pacific Northwest Laboratory

Richland, WA 99352 


\section{DISCLAIMER}

Portions of this document may be illegible in electronic image products. Images are produced from the best available original document. 


\section{Abstract}

- The TEMPEST code was exercised in a preliminary study of double-shell Tanks 241-AW101 and 241-AN-104 thermal behavior. The two-dimensional model used is derived from our earlier studies on heat transfer from Tank 241-SY-101. Several changes were made to the model to simulate the waste and conditions in 241-AW-101 and 241-AN-104. The nonconvective waste layer was assumed to be $254 \mathrm{~cm}$ (100 in.) thick for Tank $241-\mathrm{AW}-101$, and $381 \mathrm{~cm}(150 \mathrm{in}$.) in Tank 241-AN-104. The remaining waste was assumed, for each tank, to consist of a convective layer with a 7.6-cm (3-inch) crust on top. The waste heat loads for 241-AW-101 and 241-AN-104 were taken to be $10 \mathrm{~kW}(3.4 \mathrm{E} 4 \mathrm{Btu} / \mathrm{hr})$ and $12 \mathrm{~kW}(4.0 \mathrm{E} 4 \mathrm{Btu} / \mathrm{hr})$, respectively.

Present model predictions of maximum and convecting waste temperatures are within $1.7^{\circ} \mathrm{C}$ $\left(3^{\circ} \mathrm{F}\right)$ of those measured in Tanks $241-\mathrm{AW}-101$ and $241-\mathrm{AN}-104$. The difference between the predicted and measured temperature is comparable to the uncertainty of the measurement equipment. These models, therefore, are suitable for estimating the temperatures within the tanks in the event of changing air flows, waste levels, and/or waste configurations. 



\section{Summary}

Pacific Northwest Laboratory(a) conducted a study of the waste temperatures within Tanks 241-AW-101 and 241-AN-104. The objective of the study was to develop two-dimensional thermal computer models of the tanks that could be used as tools for predicting waste temperatures in these double-shell tanks for variable tank/annulus air flows and waste layer depths.

Several factors determine the temperature distribution within a double-shell waste storage tank. These factors, which are addressed by this report, include the air flows through the primary tank and annulus regions, waste stratification and the depths of the strata, thermal and physical waste properties, and the heat generation rate of the waste.

Steady-state thermal modeling of Tanks 241-AW-101 and 241-AN-104 behavior has resulted in temperatures that closely correspond with measured values. This suggests that the assumptions in these thermal models regarding waste composition, properties, and vent air flows are valid, and that our somewhat sketchy knowledge of these tanks is sufficient for analyses. Looked at another way, these models and results confirm the available data for these tanks.

(a) Pacific Northwest Laboratory is operated for the U.S. Department of Energy by Battelle Memorial Institute under Contract DE-AC06-76RLO 1830. 
..

\section{.}




\section{Contents}

Abstract $\ldots \ldots \ldots \ldots \ldots \ldots \ldots \ldots \ldots \ldots \ldots \ldots \ldots \ldots \ldots \ldots \ldots$

Summary $\ldots \ldots \ldots \ldots \ldots \ldots \ldots \ldots \ldots \ldots \ldots \ldots \ldots \ldots \ldots \ldots$

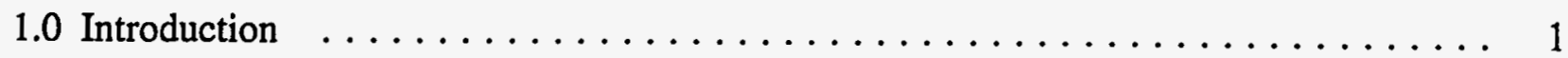

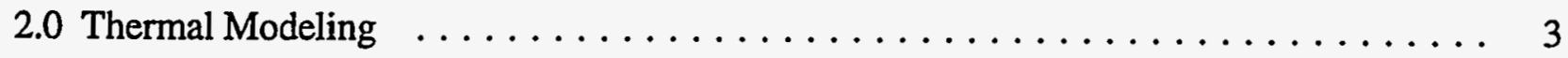

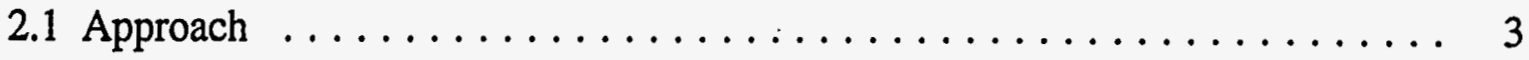

2.2 Tank Contents and Surroundings $\ldots \ldots \ldots \ldots \ldots$

2.3 Air Flows $\ldots \ldots \ldots \ldots \ldots \ldots \ldots \ldots \ldots \ldots \ldots \ldots \ldots \ldots \ldots \ldots \ldots \ldots$

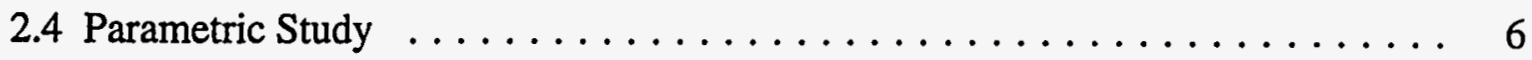

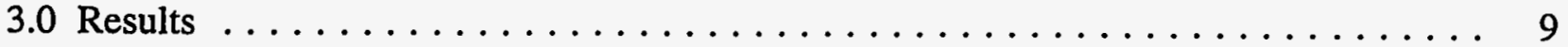

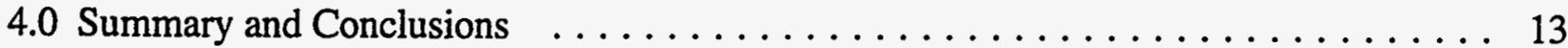

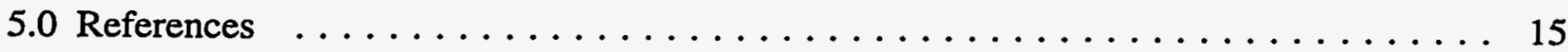




\section{Figures}

1. Schematic of Model Domain $\ldots \ldots \ldots \ldots \ldots \ldots \ldots \ldots \ldots$

2. Preliminary Predictions of Temperature Profiles for $101-\mathrm{AW} \ldots \ldots \ldots \ldots$

3. Temperature Distribution of Tank 241-AW-101 at Riser 4 A $\ldots \ldots \ldots \ldots \ldots$

4. Temperature Distribution of Tank $241-A N-104$ at Riser 4 A $\ldots \ldots \ldots \ldots$

5. Heat Flux Summary for Tanks $101-A W$ and $104-A N \ldots \ldots \ldots \ldots 11$

\section{Tables}

1. Summary of Conditions and Material Properties $\ldots \ldots \ldots \ldots$

2. Bottom Air Channel Heat Transfer Coefficients $\ldots \ldots \ldots \ldots \ldots$

3. Air Flow and Properties Study Summary (Tank $241-A W-101) \quad \ldots \ldots \ldots$

4. Comparison of Measured and Calculated 104-AN Bottom Temperatures, ${ }^{\circ} \mathrm{C}\left({ }^{\circ} \mathrm{F}\right) \ldots \ldots$ 


\subsection{Introduction}

Pacific Northwest Laboratory conducted a study of waste temperatures within underground storage Tanks 241-AW-101 and 241-AN-104 with the objective of developing two-dimensional thermal computer models of the tanks for predicting waste temperatures for variable tank/annulus air flows and waste layer depths.

Several factors determine the temperature distribution within a double-shell waste storage tank, including air flows through the primary tank and annulus regions, waste stratification and the depths of the strata, and the thermal and physical properties and heat generation rate of the waste.

Tanks 241-AW-101 (101-AW) and 241-AN-104 (104-AN) are $4.39 \mathrm{ML}$ (1.16 Mgal.) high-level waste tanks located in the 200 East Area on the Hanford Site. Both are Flammable Gas Watch List tanks with temperature profiles similar to those observed in Tank 241-SY-101 prior to pump mixing. These profiles have the isothermal and parabolic regions indicative of convective and nonconvective heat-generating layers. Tank 101-AW has had temperature profile changes following surface level drops that indicate the release of gas from a nonconvective layer (Wilkins 1994). It is unclear what happens in 104-AN following a waste level change (Reynolds 1994) due to inconsistent effects on the subsequent temperature profiles.

Tank 101-AW contains about 4.3 million liters (1.13 Mgal. or 410 in.) of double-shell slurry feed (DSSF) with a bulk specific gravity of 1.56 (Brager 1994). Roughly $96 \%$ of the waste volume currently stored in Tank 101-AW is DSSF received in May 1986. Chemical and physical analyses were performed on five samples from this particular campaign. Slurry viscosities were reported to be less than $29 \mathrm{cP}$.(a) The tank heat load is $10 \mathrm{~kW}$ (3.4E4 Btu/hr) (Wilkins 1994). An auger has been used to obtain crust samples and determine crust thickness.(b) In 1990, twelve dip samples were taken from this tank and analyzed for water content, chemical composition and density (Welsh 1991). Unknown properties are assumed to be like those of 241-SY-101. Waste temperature has been monitored by six thermocouples on a "tree" located in riser 4A. Five of the thermocouples (TCs), \#1,3,5, 7, and 11, measure waste temperature. The remaining thermocouple (TC\#17) is in the air space above the waste level. These thermocouples fail to accurately resolve the waste layer depths, which are key to predicting the waste temperature. No bottom thermocouple data are available.

Tank 104-AN contains about 4.02 million liters (1.06 Mgal., or 386 in.) of DSSF with a bulk specific gravity of 1.46. The fill history of this tank began in June 1982 and was complete by April 1985 (Brager 1994). Core samples have not been taken in this tank, but viscosity measurements of evaporator slurry samples received by 104-AN were reported to be less than $20 \mathrm{cP}$ (Pontious 1986). The heat load of the waste is $12 \mathrm{~kW}(4.0 \mathrm{E} 4 \mathrm{Btu} / \mathrm{hr})$.(c) In May 1992, one

(a) Mauss, B. M. September 18, 1986. 86-5 Evaporator Campaign: Laboratory Analyses of Samples. Internal letter 65453-86-114 to J. C. Starr. Rockwell Hanford Operations, Richland, Washington.

(b) Personal communication with T. D. Jarecki, Westinghouse Hanford Company, Richland, Washington, February 13, 1995.

(c) Wilkins, N. E. 1994. Tank 241-AW-101 Data Review. Memo 7E310-94-053, Westinghouse Hanford Company, Richland, Washington. 
of the two blowers in the annulus vent system was shut down, resulting in a decreased air flow rate and an increased average waste temperature within the tank of roughly $1^{\circ} \mathrm{C} / \mathrm{year}\left(2^{\circ} \mathrm{F} / \mathrm{yr}\right)$ (Reynolds 1994). As of February 1995, the temperature had been monitored by TCs \#1-18 on a "tree" located in riser 4A. A one-time reading of three bottom thermocouples has been obtained.(a)

(a) Personal communication with S. J. Washburn, Westinghouse Hanford Company, Richland, Washington, February 28, 1995. 


\subsection{Thermal Modeling}

\subsection{Approach}

The approach chosen for the present work was to implement a 2-D TEMPEST model developed for double-shell Tank 241-SY-101.(a) The model consisted of 52 radial cells and 66 vertical cells with variable cell spacing. Fine cell spacing was used in regions of large thermal gradients and where thermal radiation was modeled. A constant temperature of $16^{\circ} \mathrm{C}\left(60^{\circ} \mathrm{F}\right)$ was maintained in the earth at the far vertical and radial boundaries.

The model was adapted for both Tanks 101-AW and 104-AN to reflect the waste configuration and air flow rates in each tank. The model included heat transfer by conduction, convection, and radiation. Figure 1 represents a schematic of the domain under consideration. The waste was represented as three distinct layers, crust, convective waste (slurry), and nonconvective waste (sludge), each with unique thermal and physical properties as summarized in Table 1. Waste layer depths were estimated from thermocouple data. Air circulated in the dome above the crust, in channels below the tank inner shell, and between the tank annulus shells. Heat transfer with the annulus air inflow tubes was neglected as in earlier analyses;(a) the air was assumed to enter the bottom channels at the same temperature as the prescribed dome air inlet.

In the computations an initial temperature profile was assumed, and a constant (though not necessarily uniform) heat generation rate was imposed within the waste. Heat was removed by the three modes of heat transfer to a steady-state heat balance. Heat transfer at the convective/nonconvective and convective/tank shell interfaces is determined in the code by cell to cell conduction combined with heat/mass transfer associated with fluid motion (Trent and Eyler 1991). Buoyancy-driven flow in the convecting waste carries heat to the waste extremities. Heat is conducted through the crust and nonconvective waste and through the tank walls and concrete, while air flowing over the inner tank shell and crust surface removes heat from the tank via air vents. Heat radiates from the crust surface to the dome and between the tank shells in the annulus and is conducted through the surrounding earth.

\subsection{Tank Contents and Surroundings}

Table 1 represents a summary of baseline conditions and waste properties used in the simulations. Properties used for the tank structure and surrounding earth are listed in the lower portion of the table. Heat capacities chosen for the waste within each tank are those of 241-SY101 . Viscosity measurements of DSSF received by both 101-AW and 104-AN were comparable to the Tank 241-SY-101 supernatant liquid ( 29 and $20 \mathrm{cP}$ compared with $24 \mathrm{cP}$ ). Therefore, the 241-SY-101 supernate viscosity was used here for the convective layer in each tank.

(a) Antoniak, Z. I. 1994. Study of Tank 241-SY-101 Thermal Behavior Using the TEMPEST Code. PNLMIT:030394, Pacific Northwest Laboratory, Richland, Washington. 


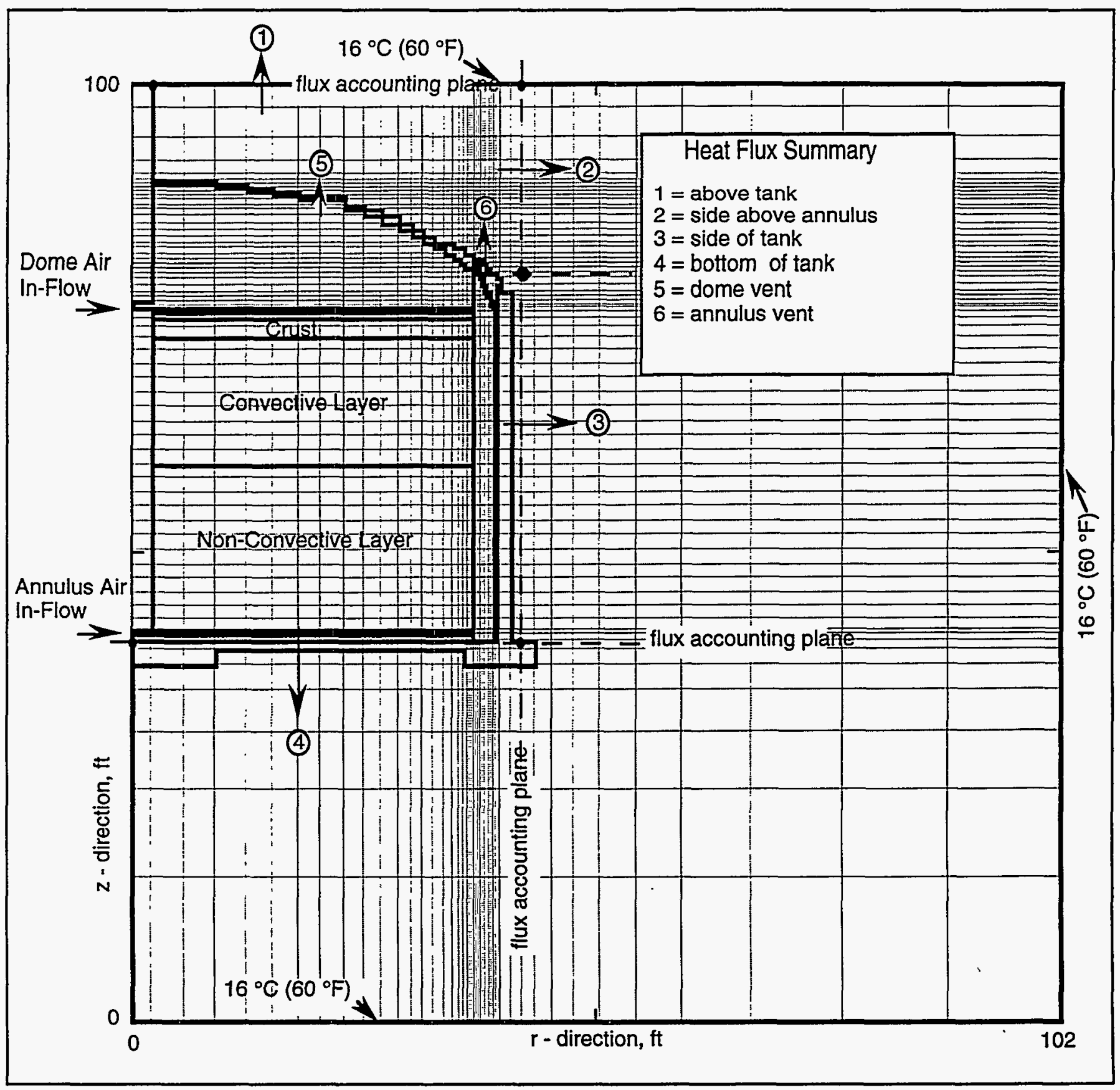

Figure 1. Schematic of Model Domain 
Table 1. Summary of Conditions and Material Properties

\begin{tabular}{|c|c|c|c|c|c|c|}
\hline $\begin{array}{l}\text { Tank Air Flows } \\
\text { dome/annulus } \\
\mathrm{m}^{3 / \mathrm{min}} \text {. } \\
\text { (cfm) }\end{array}$ & $\begin{array}{l}\text { Wáste layer } \\
\text { /depth } \\
\text { cm } \\
\text { (in.) }\end{array}$ & $\begin{array}{c}\text { Density } \\
\mathrm{kg} / \mathrm{m}^{3} \\
\left(\mathrm{lbm} / \mathrm{ft}^{3}\right)\end{array}$ & $\begin{array}{l}\text { Thermal } \\
\text { Conductivity } \\
\text { W/m-K } \\
\text { (Btu/ft-hr- }{ }^{\circ} \mathrm{F} \text { ) }\end{array}$ & $\begin{array}{c}\text { Specific Heat } \\
\mathrm{kJ} / \mathrm{kg}-\mathrm{K} \\
\left(\mathrm{Btu} / \mathrm{lbm}-{ }^{\circ} \mathrm{F}\right)\end{array}$ & $\begin{array}{c}\text { Viscosity } \\
\mathrm{cP} \\
(\mathrm{lbm} / \mathrm{ft}-\mathrm{s})\end{array}$ & $\begin{array}{c}\text { Volumetric Heat } \\
\text { generation Rate } \\
\mathrm{W} / \mathrm{m}^{3} \\
\left(\mathrm{Btu} / \mathrm{ft}^{3}-\mathrm{hr}\right)\end{array}$ \\
\hline \multirow{4}{*}{$\begin{array}{c}101-\mathrm{AW} \\
\\
4.2 / 4.2 \\
(150 / 150)\end{array}$} & $\begin{array}{l}\text { crust } / 7.6 \\
\text { (3) }\end{array}$ & $\begin{array}{l}1350 \\
(84)\end{array}$ & $\begin{array}{c}1.4 \\
(0.8)\end{array}$ & $\begin{array}{c}1.3 \\
(0.3)\end{array}$ & solid & $\begin{array}{c}2.4 \\
(0.23)\end{array}$ \\
\hline & $\begin{array}{c}\text { slurry/780 } \\
(307)\end{array}$ & $\begin{array}{l}1460 \\
(91)\end{array}$ & $\begin{array}{c}0.61 \\
(0.35)\end{array}$ & $\begin{array}{c}2.5 \\
(0.6)\end{array}$ & $\begin{array}{c}24 \\
(0.016)\end{array}$ & $\begin{array}{c}2.4 \\
(0.23)\end{array}$ \\
\hline & $\begin{array}{l}\text { sludge/254 } \\
(100)\end{array}$ & $\begin{array}{l}1670 \\
(104)\end{array}$ & $\begin{array}{c}0.66 \\
(0.38)\end{array}$ & $\begin{array}{c}2.4 \\
(0.57)\end{array}$ & solid & $\begin{array}{c}2.4 \\
(0.23)\end{array}$ \\
\hline & \multicolumn{6}{|c|}{ total $=1040(410)$} \\
\hline \multirow{4}{*}{$\begin{array}{c}104-\mathrm{AN} \\
6.2 / 5.4 \\
(220 / 190)\end{array}$} & $\begin{array}{c}\text { crust } / 7.6 \\
\text { (3) }\end{array}$ & $\begin{array}{l}1160 \\
(72)\end{array}$ & $\begin{array}{c}1.4 \\
(0.8)\end{array}$ & $\begin{array}{c}1.3 \\
(0.3)\end{array}$ & solid & $\begin{array}{c}3.0 \\
(0.29 *)\end{array}$ \\
\hline & $\begin{array}{l}\text { slurry/590 } \\
(233)\end{array}$ & $\begin{array}{l}1360 \\
(85)\end{array}$ & $\begin{array}{c}0.61 \\
(0.35)\end{array}$ & $\begin{array}{c}2.5 \\
(0.6)\end{array}$ & $\begin{array}{c}24 \\
(0.016)\end{array}$ & $\begin{array}{c}3.0 \\
(0.29)\end{array}$ \\
\hline & $\begin{array}{l}\text { sludge/380 } \\
(150)\end{array}$ & $\begin{array}{l}1620 \\
(101)\end{array}$ & $\begin{array}{c}0.66 \\
(0.38)\end{array}$ & $\begin{array}{c}2.4 \\
(0.57)\end{array}$ & solid & $\begin{array}{c}3.0 \\
(0.29)\end{array}$ \\
\hline & \multicolumn{6}{|c|}{ total $=980(386)$} \\
\hline $\begin{array}{c}\text { Structural } \\
\text { Material }\end{array}$ & \multicolumn{2}{|c|}{$\begin{array}{c}\text { Density } \\
\mathrm{kg} / \mathrm{m}^{3} \\
\left(\mathrm{lbm} / \mathrm{ft}^{3}\right)\end{array}$} & \multicolumn{2}{|c|}{$\begin{array}{c}\text { Thermal Conductivity } \\
\text { W/m-K } \\
\left(\mathrm{Btw} / \mathrm{ft}-\mathrm{hr}-{ }^{\circ} \mathrm{F}\right)\end{array}$} & \multicolumn{2}{|c|}{$\begin{array}{c}\text { Specific Heat } \\
\mathrm{kJ} / \mathrm{kg}-\mathrm{K} \\
\left(\mathrm{Btu} / \mathrm{lbm}-{ }^{\circ} \mathrm{F}\right)\end{array}$} \\
\hline $\begin{array}{l}\text { Insulating } \\
\text { concrete }\end{array}$ & \multicolumn{2}{|c|}{$2250(140)$} & \multicolumn{2}{|c|}{$0.23(0.13)$} & \multicolumn{2}{|c|}{$2.0(0.2)$} \\
\hline Steel & \multicolumn{2}{|c|}{$7860(490)$} & \multicolumn{2}{|c|}{$47(27)$} & \multicolumn{2}{|c|}{$1.1(0.11)$} \\
\hline $\begin{array}{l}\text { Concrete } \\
\text { in Walls }\end{array}$ & \multicolumn{2}{|c|}{$2250(140)$} & \multicolumn{2}{|c|}{$0.93(0.54)$} & \multicolumn{2}{|c|}{$2.0(0.2)$} \\
\hline Earth & \multicolumn{2}{|c|}{$1600(100)$} & \multicolumn{2}{|c|}{$0.78(0.45)$} & \multicolumn{2}{|c|}{$4.5(0.44)$} \\
\hline
\end{tabular}




\subsection{Air Flows}

Reliable vent air flow data for these tanks do not exist. Dome inflow is not well-controlled and occurs through leaks around pump and drainage risers (in the future, flow will be through a filter and single riser). Tank farm flow measurement uncertainty and flow rates are on the same order of magnitude. (a) The result has been to use average or best estimates for the air flow rates in Tanks 101-AW and 104-AN from recent and historical data. Based on modeling Tank 241-SY101 , (b) an annual average of $16^{\circ} \mathrm{C}\left(60^{\circ} \mathrm{F}\right)$ was used as the inflow temperature for both the primary tank (dome) and annulus regions. The effect of seasonal variations on waste temperature is quite small, about $1^{\circ} \mathrm{C}\left(2^{\circ} \mathrm{F}\right)$ based on the results of Tank 241-SY-101 studies.(c)

Convective heat transfer coefficients for the bottom air channels were calculated using a spread sheet and are average values for each of the three lengths of channel extending from the center manifold to the annulus. Coefficients used in the simulations are listed in Table 2.

\subsection{Parametric Study}

Several attempts were made at simulating the thermal condition of Tank 101-AW. The effect of converging on a thermal solution for 101-AW was to test the model for sensitivity to heat generation rate, waste conductivity, air flow rate, and crust layer thickness. The crust layer thickness was unknown when this analysis began, air flow numbers were sketchy; a range of the heat loads from grab samples were provided (Welsh 1991), and the waste conductivity was assumed to be the same as that of Tank 241-SY-101. The cases run are summarized in Table 3;

Table 2. Bottom Air Channel Heat Transfer Coefficients

\begin{tabular}{||c|c|c|c|c||}
\hline \multirow{2}{*}{ Tank } & \multirow{2}{*}{$\begin{array}{c}\text { Annulus Flow } \\
\text { Rate. } \\
\mathrm{m}^{3 / m i n}(\mathrm{cfm})\end{array}$} & \multicolumn{3}{|c|}{$\begin{array}{c}\text { Heat Transfer Coefficient } \\
\text { W/m2-K }\left(\mathrm{Btu} / \mathrm{h} \mathrm{ft}{ }^{\circ} \mathrm{F}\right)\end{array}$} \\
\cline { 3 - 5 } & Innermost Channel & Mid-Channel & Outermost Channel \\
\hline \hline 101-AW & $4.2(150)$ & $3.7(0.66)$ & $4.3(0.76)$ & $5.1(0.90)$ \\
\hline 101-AW & $8.4(300)$ & $6.8(1.2)$ & $7.4(1.3)$ & $9.1(1.6)$ \\
\hline 104-AN & $5.4(190)$ & $4.5(0.80)$ & $5.2(0.92)$ & $6.2(1.1)$ \\
\hline
\end{tabular}

(a) Personal communication with S. R. Pierce, Westinghouse Hanford Company, Richland, Washington, February 28, 1995.

(b) Antoniak, Z. I. 1994. Study of Tank 241-SY-101 Thermal Behavior Using the TEMPEST Code. PNLMIT:030394, Pacific Northwest Laboratory, Richland, Washington.

(c) Antoniak, Z. I., and K. P. Recknagle. 1995. Detailed Studies of Tank 241-SY-101 Thermal Behavior Using the TEMPEST Code (Draft). Pacific Northwest Laboratory, Richland, Washington. 
Figure 2 shows Cases 1, 2, and 3 compared with temperatures measured on December 19, 1994. Note that the measured temperatures are unreliable; for example, the reference junction temperature varies with ambient conditions (Wilkins 1994).

As shown in Case 1 in Table 3 and Figure 2, sludge conductivity of $1.4 \mathrm{~W} / \mathrm{m}-\mathrm{K}$ resulted in low sludge layer temperatures compared with those measured. The thermal conductivity of the sludge was reduced to $0.66 \mathrm{~W} / \mathrm{m}-\mathrm{K}$ (that of water) for Case 2 and all remaining cases. Figure 2 illustrates the effect of the reduced sludge conductivity as the temperature bulge in the sludge layer for Cases 2 and 3. Heat load data ranged from 2.2E-4 W/100 mL (7.6E-4 Btu/hr/100 mL) for samples taken from the convective layer, to $2.6 \mathrm{E}-4(9.0 \mathrm{E}-4)$ for samples from the nonconvective layer. Case 3 was run using a low single sample value for the convective waste heat load and a high value for the nonconvecting waste. Cases 4-6 were run using high heat load values for the convective and nonconvective layers with the crust layer reduced to $7.6 \mathrm{~cm}$; a video taken in 101 AW and auger sampling indicate a very thin crust layer. In Case 5, the crust conductivity was increased from 1.4 to $170 \mathrm{~W} / \mathrm{m}-\mathrm{K}$. Inspection of the table shows that, for a thin $(7.6 \mathrm{~cm}) \mathrm{crust}$, the crust layer conductivity had no effect on the waste temperature. Case 6 , which used updated vent flow data, over-predicted the waste temperatures. Case 7, as in the early runs, used a uniform bulk average heat load value corresponding to a total of $10 \mathrm{~kW}\left(2.4 \mathrm{~W} / \mathrm{m}^{3}\right)$. This heat load, along with the other parameters shown for Case 7, yielded the best results when compared with measured temperatures.

Parameters were chosen similarly to Case 7 to obtain a thermal solution for Tank 104-AN. The total tank heat load was distributed evenly throughout the waste. Waste conductivities used for Tank 101-AW were adopted for 104-AN. Photos taken in the dome space of 104-AN indicate a thin crust (Brager 1994); the crust thickness was taken to be $7.6 \mathrm{~cm}$ as for 101-AW. Vent flow data from December 1994 were used for the air flow rates. Final results of simulations of each tank are discussed in the following section. 
Table 3. Air Flow and Properties Study Summary (Tank 241-AW-101)

\begin{tabular}{|c|c|c|c|c|c|c|c|c|}
\hline \multirow[b]{2}{*}{ Case } & \multirow{2}{*}{$\begin{array}{l}\text { Flow Rate } \\
\text { dome/ann } \\
\mathrm{m}^{3 / \mathrm{min}} \text {. } \\
\text { (cfm) }\end{array}$} & \multirow{2}{*}{$\begin{array}{l}\text { Crust } \\
\text { Layer } \\
\text { Depth } \\
\text { cm } \\
\text { (in.) }\end{array}$} & \multirow{2}{*}{$\begin{array}{c}\text { Crust/Sludge } \\
\text { Conductivity } \\
\text { W/m-K } \\
\text { (Btu/ft-hr-F) }\end{array}$} & \multicolumn{3}{|c|}{$\begin{array}{c}\text { Heat Generation Rate } \\
\text { - by Waste Layer } \\
\mathrm{W} / \mathrm{m}^{3}\left(\mathrm{Btu} / \mathrm{ft}^{3}-\mathrm{hr}\right)\end{array}$} & \multirow{2}{*}{$\begin{array}{l}\text { Maximum } \\
\text { Temp } \\
{ }^{\circ} \mathrm{C} \\
\left({ }^{\circ} \mathrm{F}\right)\end{array}$} & \multirow{2}{*}{$\begin{array}{c}\text { Convecting } \\
\text { Waste Temp } \\
{ }^{\circ} \mathrm{C} \\
\left({ }^{\circ} \mathrm{F}\right)\end{array}$} \\
\hline & & & & Crust & Slurry & Sludge & & \\
\hline 1 & $\begin{array}{c}4.2 / 8.4 \\
(150 / 300)\end{array}$ & $\begin{array}{c}76 \\
(30)\end{array}$ & $\begin{array}{c}1.4 / 1.4 \\
(0.8 / 0.8)\end{array}$ & $\begin{array}{c}2.4 \\
(0.23)\end{array}$ & $\begin{array}{c}2.4 \\
(0.23)\end{array}$ & $\begin{array}{c}2.4 \\
(0.23)\end{array}$ & $\begin{array}{c}39 \\
(103.0)\end{array}$ & $\begin{array}{c}39 \\
(103.0)\end{array}$ \\
\hline 2 & $4.2 / 8.4$ & 76 & $\begin{array}{c}1.4 / 0.66 \\
(0.8 / 0.38)\end{array}$ & 2.4 & 2.4 & 2.4 & $\begin{array}{c}40.0 \\
(104.0)\end{array}$ & $\begin{array}{c}39.4 \\
(102.9)\end{array}$ \\
\hline 3 & $4.2 / 8.4$ & 76 & $1.4 / 0.66$ & $\begin{array}{c}2.3 \\
(0.22)\end{array}$ & $\begin{array}{c}2.3 \\
(0.22)\end{array}$ & $\begin{array}{c}2.7 \\
(0.26)\end{array}$ & $\begin{array}{c}40.1 \\
(104.2)\end{array}$ & $\begin{array}{c}39.1 \\
(102.4)\end{array}$ \\
\hline 4 & $4.2 / 8.4$ & $\begin{array}{l}7.6 \\
(3)\end{array}$ & $1.4 / 0.66$ & $\begin{array}{c}2.5 \\
(0.24)\end{array}$ & $\begin{array}{c}2.5 \\
(0.24)\end{array}$ & $\begin{array}{c}2.7 \\
(0.26)\end{array}$ & $\begin{array}{c}40.2 \\
(104.4)\end{array}$ & $\begin{array}{c}38.9 \\
(102.0)\end{array}$ \\
\hline 5 & $4.2 / 8.4$ & 7.6 & $\begin{array}{c}173 / 0.66 \\
(100 . / 0.38)\end{array}$ & 2.5 & 2.5 & 2.7 & $\begin{array}{c}40.2 \\
(104.4)\end{array}$ & $\begin{array}{c}38.9 \\
(102.0)\end{array}$ \\
\hline 6 & $\begin{array}{c}4.2 / 4.2 \\
(150 / 150)\end{array}$ & 7.6 & $1.4 / 0.66$ & 2.5 & 2.5 & 2.7 & $\begin{array}{c}44.6 \\
(112.3)\end{array}$ & $\begin{array}{c}42.8 \\
(109.0)\end{array}$ \\
\hline 7 & $4.2 / 4.2$ & 7.6 & $1.4 / 0.66$ & 2.4 & 2.4 & 2.4 & $\begin{array}{c}42.7 \\
(108.8)\end{array}$ & $\begin{array}{c}41.1 \\
(106.0)\end{array}$ \\
\hline
\end{tabular}

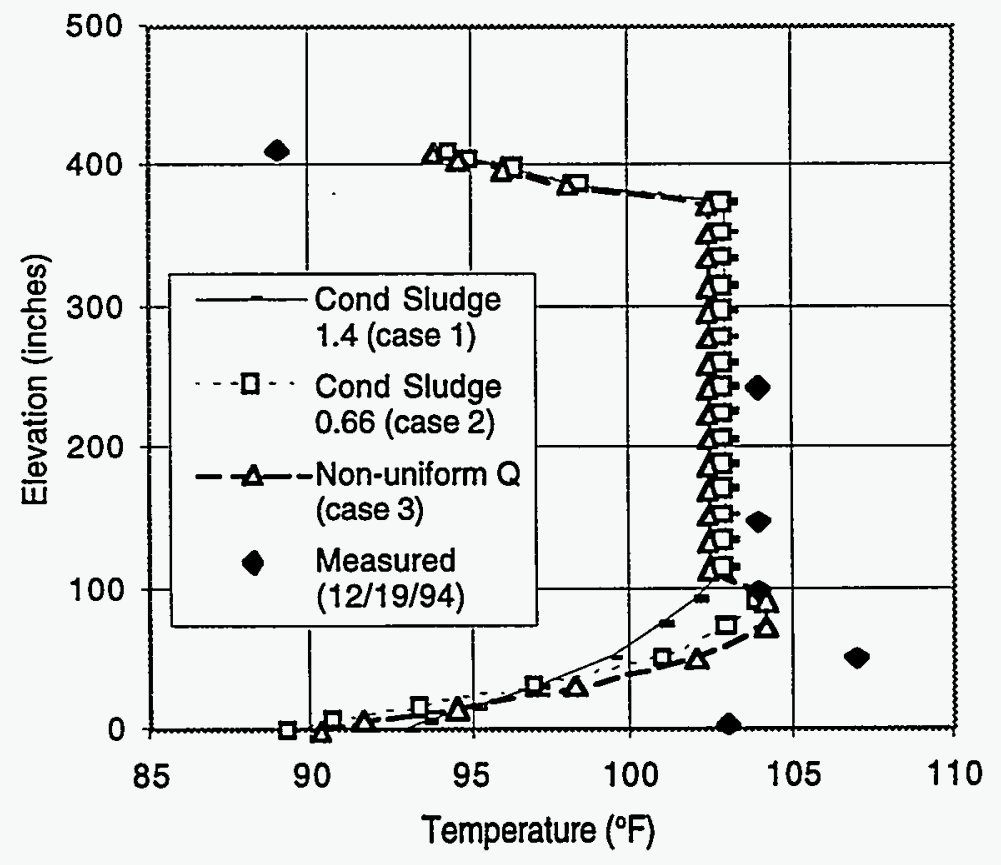

Figure 2. Preliminary Predictions of Temperature Profiles for 101-AW 


\subsection{Results}

Figure 3 represents the vertical temperature distribution of Tank 241-AW-101 at riser 4A. Discrete data points shown are temperatures measured on December 19, 1994, and the solid line is the model estimated temperature. Note that temperatures near the crust/convecting waste interface were not measured. A difference of as much as $1^{\circ} \mathrm{C}\left(2^{\circ} \mathrm{F}\right)$ exists between the estimated and measured temperatures throughout the bulk of the waste, which is within the uncertainty of the measurements.(a) The exception to this is near the tank bottom, where the predicted temperature is about $3^{\circ} \mathrm{C}\left(5^{\circ} \mathrm{F}\right)$ lower than measured. The actual annulus air flow may be lower than that assumed in the model and could cause the under-predicted temperature near the tank bottom; test cases shown in Figure 2 had annulus flows of $8.4 \mathrm{~m} 3 / \mathrm{min}(300 \mathrm{cfm})$ and under-predicted the bottom temperature by 6 to $7^{\circ} \mathrm{C}\left(10\right.$ to $\left.13^{\circ} \mathrm{F}\right)$. Calculated air exhaust temperatures for the dome and annulus regions were $38^{\circ} \mathrm{C}\left(100^{\circ} \mathrm{F}\right)$ and $40^{\circ} \mathrm{C}\left(104^{\circ} \mathrm{F}\right)$, respectively.

Results of the simulation of Tank 241-AN-104 are shown graphically in Figure 4. Discrete data points shown are temperatures measured on February 14,1995, and the solid line is the calculated temperature. The calculated waste temperature for this tank, throughout the bulk of the waste, is within $1.7^{\circ} \mathrm{C}\left(3^{\circ} \mathrm{F}\right)$ of the measured temperatures. Here again, near the tank bottom, the difference between the predicted and measured temperatures is about $3^{\circ} \mathrm{C}\left(5^{\circ} \mathrm{F}\right)$ lower than that measured. Predicted temperatures are compared with bottom thermocouple data in Table 4; considering all the uncertainties regarding this tank, agreement between measured and calculated temperatures is considered acceptable. Calculated air exhaust temperatures for the dome and annulus regions were $38^{\circ} \mathrm{C}\left(100^{\circ} \mathrm{F}\right)$ and $41^{\circ} \mathrm{C}\left(106^{\circ} \mathrm{F}\right)$, respectively.

Calculated heat losses from Tanks 101-AW and 104-AN are summarized in Figure 5; locations of the heat transfer regions shown are illustrated in Figure 1. At lower air flow rates, a larger percentage of heat is removed by the earth and less by the air vents. Tank 101-AW lost 29\% of its heat radially, through the tank walls, $19 \%$ escaped with the dome air flow, and $20 \%$ with the annulus air flow. Tank 104-AN, which had larger air inflows, lost only $22 \%$ of its heat through the tank walls, $32 \%$ with the dome air flow, and $20 \%$ with the annulus air.

(a) Brewster, M. E., E. J. Eschbach, and Z. I. Antoniak. Uncertainty Status of Selected Instruments in Tank 241-SY-101. PNLMIT:013095, Pacific Northwest Laboratory, Richland, Washington. 


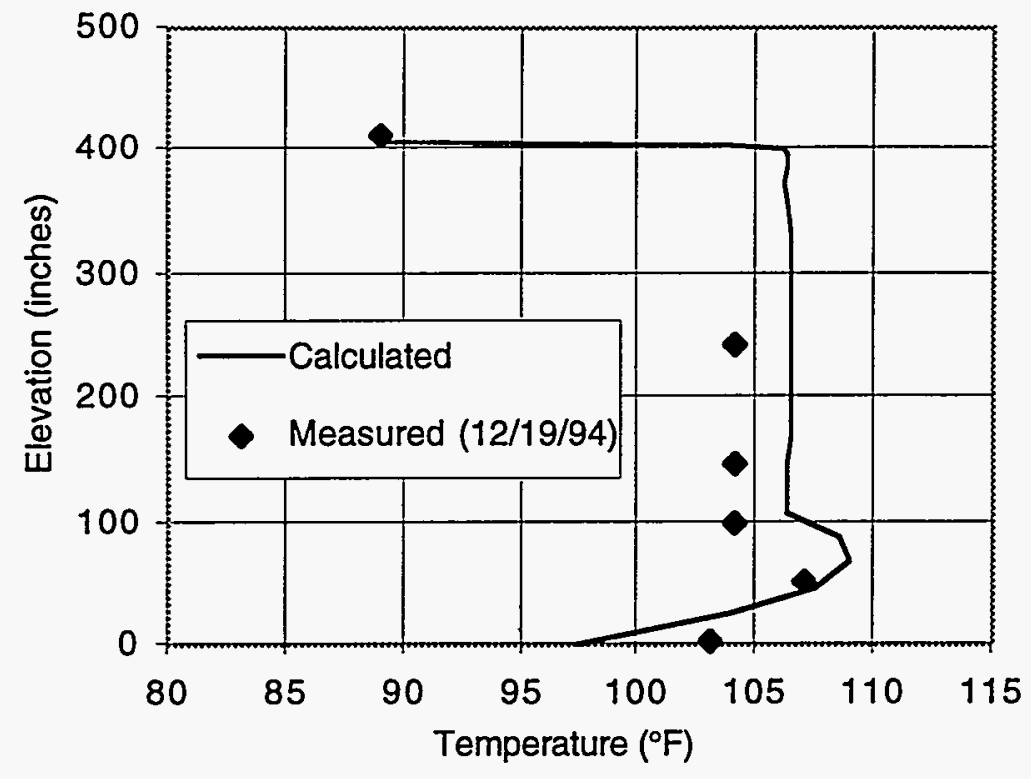

Figure 3. Temperature Distribution of Tank 241-AW-101 at Riser 4A

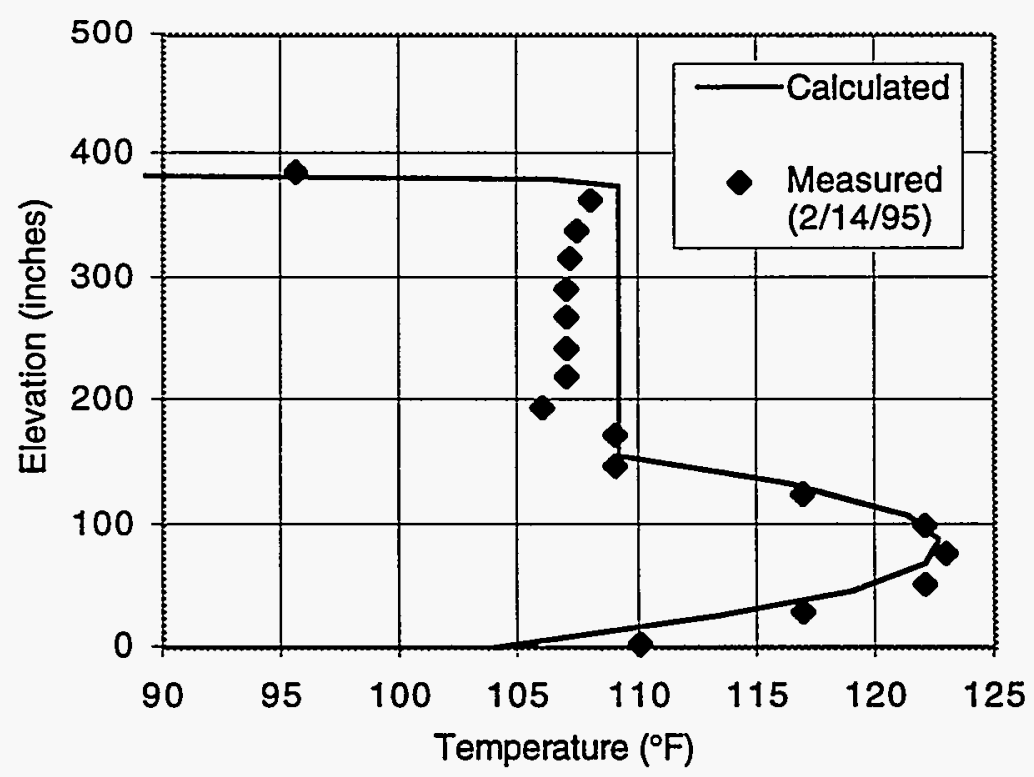

Figure 4. Temperature Distribution of Tank 241-AN-104 at Riser 4A 
Table 4. Comparison of Measured and Calculated 104-AN Bottom Temperatures, ${ }^{\circ} \mathrm{C}\left({ }^{\circ} \mathrm{F}\right)$

\begin{tabular}{||c|c|c|c||}
\hline Data Source & $\begin{array}{c}\text { Radius }=210 \mathrm{~cm} \\
(7 \mathrm{ft})\end{array}$ & $\begin{array}{c}\text { Radius }=640 \mathrm{~cm} \\
(21 \mathrm{ft})\end{array}$ & $\begin{array}{c}\text { Radius }=1100 \mathrm{~cm} \\
(36 \mathrm{ft})\end{array}$ \\
\hline \hline $\begin{array}{c}\text { Measured } \\
\text { (at 4:00 pm on 2/27/95) }\end{array}$ & $37\left(99^{\circ} \mathrm{F}\right)$ & $40\left(104^{\circ} \mathrm{F}\right)$ & $36\left(97^{\circ} \mathrm{F}\right)$ \\
\hline $\begin{array}{c}\text { Calculated } \\
\text { (steady-state) }\end{array}$ & $32\left(90^{\circ} \mathrm{F}\right)$ & $39\left(103^{\circ} \mathrm{F}\right)$ & $34\left(93^{\circ} \mathrm{F}\right)$ \\
\hline
\end{tabular}
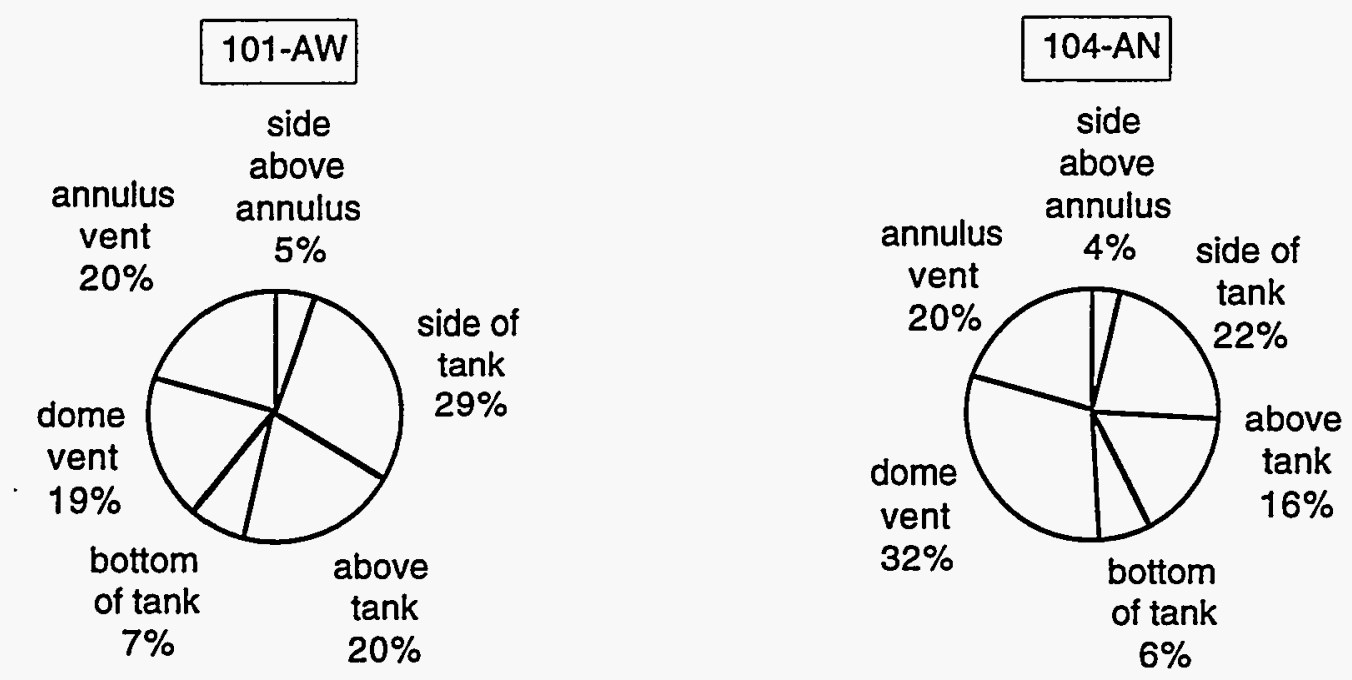

Figure 5. Heat Flux Summary for Tanks 101-AW and 104-AN 


\subsection{Summary and Conclusions}

Steady-state thermal modeling of Tank 101-AW and 104-AN behavior has resulted in temperatures that closely correspond to measured values. This suggests that the assumptions in these thermal models regarding waste composition, properties, and vent air flows are valid, and that our somewhat sketchy knowledge of these tanks is sufficient for analyses. Looked at another way, these models and results confirm the available data for these tanks. These models, therefore, are suitable for estimating the temperatures within the tanks in the event of changing air flows, waste levels, and/or waste configurations. 
_. . . $\ldots .$.

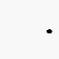

\section{.}




\subsection{References}

Brager, H. R. 1994. Summary of Information on Flammable Gas Watch List Tanks. WHC-EP0711, Westinghouse Hanford Company, Richland, Washington.

Pontious, N. L. 1986. 242-A Evaporator/Crystallizer FY 1985 Campaign 85-3 Post-Run . Document. SD-WM-PE-023 Rev. 0, Rockwell Hanford Operations, Richland, Washington.

Reynolds, D. A. 1994. Evaluation of 241-AN Tank Farm Flammable Gas Behavior. WHC-EP0717, Westinghouse Hanford Company, Richland, Washington.

Trent, D. S., and L. L. Eyler. 1991. TEMPEST - A Computer Program for Three-Dimensional Time-Dependent Hydrothermal Analysis. PNWD-1536 Vol. 1, Rev. 1, Pacific Northwest Laboratory, Richland, Washington.

Welsh, T. L. 1991. Tank 241-AW-101 Characterization Results, WHC-SD-WM-TRP-055 Rev. 0 , Westinghouse Hanford Company, Richland, Washington.

Wilkins, N. E. 1994. Evaluation of Tank 241-AW-101 Flammable Gas Tank Behavior. WHCSD-WM-TI-617 Rev. 0, Westinghouse Hanford Company, Richland, Washington. 
PNL-10683

UC-510

\section{DISTRIBUTION}

No. of

Copies

\section{OFFSITE}

2 DOE/Office of Scientific and

Technical Information

B. S. Hudson

P.O. Box 271

Lindsborg, KA 67456

K. Pasamehmetlogu

Mailstop K575

Los Alamos National Laboratory

Los Alamos, NM 87545

\section{ONSITE}

3 DOE Richland Operations Office

J. M. Gray

S7-54

M.F. Jarvis

G. Rosenwald
No. of

Copies

9 Westinghouse Hanford Company

G. D. Johnson (5)

S7-15

J. W. Lentsch

S7-12

E. J. Lipke

S7-14

N. G. McDuffie

S7-15

R. J. Van Vleet

H4-62

29 Pacific Northwest Laboratory

Z. I. Antoniak (5)

K7-15

S. Q. Bennett

J. W. Brothers (5)

K7-90

J. A. Fort

K5-22

P. A. Gauglitz

J. D. Hudson

K7-15

P7-41

K7-15

T. E. Michener

K7-15

F. E. Panisko

P8-34

K. P. Recknagle (5)

K7-15

H. C. Reid

K7-15

A. Shekarriz

K7-15

C. W. Stewart

K7-15

D. S. Trent

K7-15

P. D. Whitney

Information Release (3) 